\title{
Unifikasi Hukum Nasional Dalam Tindak Pidana Pembunuhan Berlatar Belakang Hukum Adat ${ }^{1}$
}

\author{
Andika Wahyudi Gani dan Muhammad Takbir \\ Universitas Negeri Makassar dan UIN Alauddin Makassar \\ Jln. A.P. Pettarani, Tidung, Makassar, dan Jln. Yasin Limpo, Samata, Gowa \\ andikawgani@unm.ac.id dan abhimalliongi@gmail.com
}

Received: 3 Desember 2019; Accepted: 3 Februari 2020; Published: 29 Juni 2020

DOI: 10.20885/iustum.vol27.iss1.art6

\begin{abstract}
This research describes the form of unification of national law on legal plurality in Indonesia. This is a case study research conducted in two regions in South Sulawesi, namely Jeneponto and Gowa Regencies. The aim is to investigate the unequal legal relations between positivistic national law and customary law. The methods used Werner Menski socio-legal approach and legislation approach. The results of this study are, first, law enforcers, in this case the Public Prosecutor and the Panel of Judges, in deciding cases only refer entirely to the law while ignoring customary law. On the other hand the defendant believes instead that his actions to be the right actions and should not be regretted based on his customary law. This is because of its position as a community law enforcer. Second, national law stands very dominant from other laws, especially customary law.
\end{abstract}

Keywords: Customary law; national law; legal plurality; South Sulawesi

\section{Abstrak}

Penelitian ini mendeskripsikan bentuk unifikasi hukum nasional terhadap pluralitas hukum di Indonesia. Penelitian ini adalah penelitian studi kasus yang dilakukan di dua daerah di Sulawesi Selatan yakni, Kabupaten Jeneponto dan Gowa. Tujuannya adalah untuk menelisik relasi hukum yang timpang di antara hukum nasional yang positivistik dan hukum adat. Pendekatan yang digunakan adalah socio-legal Werner Menski dan perundang-undangan. Hasil dari penelitian ini adalah, pertama, penegak hukum, dalam hal ini Jaksa Penuntut Umum dan Majelis Hakim, dalam memutus perkara sepenuhnya hanya mengacu pada undang-undang dan mengabaikan hukum adat. Sementara pada sisi lain terdakwa juga memandang tindakannya merupakan tindakan yang benar dan tak perlu disesalkan berdasarkan hukum adatnya. Ini karena posisinya juga sebagai penegak hukum masyarakat. Kedua, hukum nasional berdiri sangat dominan dari hukum-hukum lainnya, khsusunya hukum adat.

Kata-kata Kunci: Hukum adat; hukum nasional; pluralitas hukum; Sulawesi Selatan

1 Artikel ini merupakan salah satu bagian dari disertasi Penulis di Fakultas Hukum Universitas Gadja Mada dengan judul, Eksistensi Nilai Budaya siri' na pacce Terhadap Tindak. Pidana Pembunuban Berdasarkan Asas Legalitas Pada Masyarakat Bugis-Makassar, 2019 


\section{Pendahuluan}

Indonesia adalah negara hukum. Ini terang ditegaskan dalam Pasal 1 ayat (3) Undang-Undang Dasar Negara Republik Indonesia Tahun 1945 (UUD NRI 1945), bahwa "Negara Indonesia adalah Negara Hukum. Negara hukum yang dimaksud tidaklah seutuhnya sesuai dengan dua konsep negara hukum terbesar saat ini, yaitu rechtstaat ${ }^{2}$ yang mengacu pada sistem hukum eropa kontinentinental dan rule of law $w^{3}$ yang mengacu pada sistem hukum dari negara anglo-saxon. Kendati demikian, menurut Mahfud MD, kenyataan sosiologis di Indonesia lebih identik membawa Indonesia pada sistem konstutisi jenis kedua, rule of law, sebagai pilar yang menjamin hak-hak warganya. ${ }^{4}$

Menurut Satjipto Rahardjo, ${ }^{5}$ di Indonesia, konsep rechtsstaat sulit digunakan mengingat hukum negara harus berinteraksi dengan jenis-jenis hukum lainnya yang telah hidup dan mapan (living law). Terlebih lagi, realitas kebangsaan di negeri ini berdiri di atas keragaman etnik, budaya, dan agama. Pada masingmasing suku dan etnik terdapat hukum adat yang tidak hanya sebagai rule of law, tetapi juga sebagai way of life, sehingga hukum nasional dituntut untuk bersifat akomodatif dan fasilitatif terhadap pluralitas hukum tersebut dalam upaya menjawab kebutuhan bangsa.

Hal seturut juga diterangkan oleh Romli Atmasasmita, ${ }^{6}$ bahwa konsep negara hukum bukan hanya tentang keberhasilan memproduksi undang-undang dan peraturan-peraturan lainnya, tetapi juga dapat dipahami oleh masyarakat,

${ }^{2}$ Rechtstaat, meskipun memiliki arti yang sama, negara hukum, namun dari aspek kelahirannya dari suatu perjuangan revolusioner di Eropa. Oleh sebab itu, hukum ini disebut juga sebagai civil law atau modern roman. Adapun ciri-cirinya adalah: formal, teoritis-konseptual, statis, klasik, peran negara bersifat pasif dan kewanangan yang kecil. Ini berbeda dengan sistem Rule of Law yang memiliki ciri adalah: praktis-operesional dan bersumber dari common law, mengacu pada hukum material, bersifat dinamis, peran negara bersifat aktif dan kewenangnya besar. Lihat, Jeffry Alexander Ch. Likadja, "Memaknai 'Hukum Negara (Law Through State)' dalam Bingkai "Negara Hukum (Rechtstaat)", Jurnal Hasanuddin Law Review, Vol. 1, No. 1, 2015, hlm. 79-80

${ }^{3}$ Istilah Rule of Law mengalami perkembangan dan telah menjadi pembahasan yuris dalam konferensi internasional seperti di Athena tahun 1955, di New Delhi tahun 1959, di Lagos Nigeria tahun 1961, di Rio di Jainero, Brasil tahun 1962, dan terakhir di Bangkok tahun 1965. Pada intinya, The Rule of Law, dalam penyelenggaraan pemerintahan mensyarakatkan 6 hal, yakni; 1) Perlindungan Konstitusional dalam arti perlindungan hak asasi manusia; 2) Pengadilan yang bebas; 3) Pemilihan Umum yang bebas; 4) Kebebasan menyetakan pendapat; 5) Kebebasan politik; 6) Pendidikan kewarganegaraan. Lihat, Imam Suhadi, "Hukum dan kekuasaan", Jurnal Hukum, Vol. 3, No. 6, 1994, hlm. 47

${ }^{4}$ Moh. Mahfud MD., Hukum dan Pilar-Pilar Demokrasi, Gama Media, Yogyakarta, 1999, hlm. 22-24

${ }^{5}$ Satjipto Raharjo, Negara Hukum yang Membahagiakan Rakyatnya, Genta Publishing, Yogyakarta, 2009, hlm. 60-61

${ }^{6}$ Romli Atmasasmita, Teori Hukum Integratif (Rekonstruksi Terbadap Teori Hukum Pembangunan dan Teori Hukum Progresif, Genta Publishing, Yogyakarta, 2012, hlm. 17 
mulai pada tingkat filosofis, sosiologis, yuridis, hingga teleologis. Selain itu, baginya, hukum juga bukan semata tentang pembagian tugas menyelenggarakan lembaga negara berikut aparaturnya, melainkan juga dapat menjadi moral design dalam usaha mewujudkan tujuan yang dikandungnya. ${ }^{7}$

Indonesia meskipun mengakui bahwa sistem hukum nasionalnya merupakan hasil kompilasi dan campuran dari berbagai sistem hukum, yakni: agama, adat, dan hukum kolonial, namun yang disebutkan terakhir tampak dominan dari dua jenis hukum lainnya. Hukum agama dan hukum adat seringkali dipandang sebagai pelengkap dari hukum negara kolonial yang banyak diadaptasi dan dicangkokkan oleh hukum negara. Seperti diterangkan oleh Maria S.W. Sumardjono, ${ }^{8}$ ruang terbuka perlakuan pluralisme hukum di Indonesia hanya untuk melengkapi hukum negara.

Pada konteks ini, setidaknya terdapat tiga persoalan dalam hukum nasional sejauh ini, yaitu (i) labelling negara hukum merupakan kenyataan yang tampak "dipaksakan" karena tidak melewati proses pergulatan sosial yang panjang seperti yang terjadi di Eropa, bahkan mengalami lompatan sistem sosial, dari tradisional-feodalistik ke negara hukum99, (ii) kuatnya determinasi hukum kolonial dalam sistem hukum nasional, dan (iii) hukum adat dan agama yang hidup dan mapan di tengah masyarakat hanya dipandang sebagai pelengkap dari hukum nasional.

Ketiga persoalan ini tentu saja tidak dapat diabaikan, mengingat putusanputusan hukum saat ini mengacu pada legalitas sistem hukum yang berlaku. Implikasi dari tiga kerangka ini adalah pertama, hilangnya spirit of law seperti yang diharapkan dalam rule of law. Ini karena sumber yang sejatinya menjadi rujukan hukum, yaitu common law, tergantikan oleh hukum kolonial, dan negara yang sejatinya aktif justru menjadi pasif seperti layaknya sistem rechtstaat.

Kedua, determinasi hukum kolonial yang karakteristiknya bersifat positivistik dan hierarkis-univikatif. Positivistik, yakni jenis hukum harus mengacu pada hukum yang tertulis, sedangkan hierarkis-univikatif, yakni hukum

${ }^{7}$ Satjipto Raharjo, Op.Cit,. hlm. 92

${ }^{8}$ Maria S.W. Sumardjono, "Pluralisme Hukum dalam Pengaturan Sumber Daya Alam di Indonesia, Adaptasi, Harmonisasi dan Agenda ke Depan", disampaikan pada Rapat Senat Terbuka dalam rangka Dies Natalis ke-71, Fakultas Hukum, Universitas Gadjah Mada, 2017, hlm. 8

9Sudjito, Hukum Dalam Pelangi Kehidupan, Gadjah Mada University Press, Yogyakarta, 2012, hlm. 58 
yang menempatkan hukum positif tersebut dalam derajat yang paling atas sebagai sumber dari segala atuan hukum. Antonio Boggiano sebagaimana dikutip dalam Anton F. Susanto ${ }^{10}$ menjelaskan, dalam paradigma positivisme hukum, pembahasan moralitas atau moralitas hukum sedapat mungkin dihindari. Sementara itu, hukum tidak semata tertulis dalam undang-undang, tapi juga ada yang tidak tertulis. Seperti diterangkan oleh Atmasasmita ${ }^{11}$ dengan merujuk pada van Apeldoorn, hukum bukan hanya undang-undang dan deretan pasal-pasal belaka, tetapi lebih jauh dari itu, hukum juga tentang norma dan moralitas yang hidup dan berkembang di dalam masyarakat.

Ketiga, implikasi dari dua penjelasan tersebut adalah terabaikannya realitas hukum yang telah mapan dan puluralistis (plurality of law) di tengah masyarakat atau living law. Realitas kebangsaan yang merupakan senyawa dari ragam etnik dari Sabang sampai Merauke, dan dari Miangas hingga pulau Rote, pada gilirannya terhomogenkan dalam satu kerangka hukum nasional yang sudah problematis sejak awal. Hakim yang sejatinya merupakan personifikasi hukum dalam mewujudkan tujuannya, yaitu keadilan, kepastian, dan kemanfaatan, mereduksi hukum hanya pada level teks dan manuskrip belaka. Seperti diterangkan oleh Bagir Manan, ${ }^{12}$ hakim adalah tidak lain merupakan corong undang-undang, spreeebuis van de wet, bouche de la hoi. Ini dikuatkan, misalnya, melalui Putusan Mahkamah Agung No.178 K/Kr/1959 pada 8 Desember 1959 (Yurisprudensi Mahkamah Agung), bahwa:

"hakim bertugas semata-mata untuk melakukan undang-undang yang berlaku dan tidak dapat menguji nilai atau keadilan suatu peraturan perundang-undangan atau pernyataan bahwa karena unsur-unsur tindak pidana yang dinyatakan dalam surat dakwaan tidak terbukti, terdakwa harus dibebaskan dari segala tuduhan".

Putusan Mahkamah Agung (MA) ini mengisyaratkan pemisahan hukum dari moralitas secara divergen. Hukum pada sisi ini lebih mengarusutamakan asas kepastian daripada asas keadilan, sehingga hakim yang diharapkan

10 Anthon F. Susanto, Ilmu Hukum Non Sistematik: Pondasi Filsafat Pengembangan Ilmu Hukum Indonesia, Genta Publishing, Yogyakarta, 2010, hlm. 80

${ }^{11}$ Romli Atmasasmita, Teori Hukum..., Op. Cit., hlm. 17 hlm. 3

12 Bagir Manan, "Mengadili Menurut Hukum", Majalah Hukum Varia Peradilan, No. 238, Jakarta, 2005, 
menegakkan keadilan, justru dalam wewenangnya bertindak sebagai eksekutor teks. Akibatnya, terjadi kegaduhan di banyak tempat di Indonesia. Bahkan, pada 1998-2004, terjadi gelombang massa yang ingin kembali pada nativisme kultural yang mengacu pada hukum adat. Konflik pun pada akhirnya menjadi tidak terhindarkan. Apabila melacak asal-usulnya, kenyataan ini berakar dari ketidakpuasan masyarakat terhadap pemberlakukan sistem hukum nasional.

Berangkat dari persoalan yang telah dipaparkan, disorot dua kasus pembunuhan di Sulawesi Selatan yang ditangani oleh pengadilan negeri di Kabupaten Jene'ponto dan Gowa pada 2018 yang melibatkan hukum adat. Kedua kasus pembunuhan ini bermoduskan hukum adat, namun hakim tidak memasukkan pertimbangan hukum adat sama sekali, baik untuk memberatkan maupun meringankan. Dalam konteks ini, hukum adat yang berangkat dari nilai menjadi terabaikan. Terlebih lagi, sistem hukum adat di dua tempat ini kuat dan terpelihara dari generasi ke generasi. Seperti diterangkan oleh Hamid Abdullah, adatdan hukum adat dalam masyarakat Bugis-Makassar merupakan sesuatu yang inheren dalam padangan hidupyang pada gilirannya membentuk norma dan institusi sosial merekaserta membentuk perilaku sosial dan way of life-nya. Perangkat-perangkat ini terintegrasi satu sama lain membentuk sebuah harmoni dalam waktu yang lama pada masyarakat ini. ${ }^{13}$

Terdapat perbedaan pandangan antara hakim, jaksa, dan masyarakat adat tentang siapa yang disebut pelaku dan siapa yang disebut korban dalam penyelesaian kasus tersebut. Menurut hakim dan jaksa, subjek korban mengacu pada orang yang terbunuh dan orang-orang yang membunuh selanjutnya disebut sebagai pelaku, sedangkan dalam pandangan masyarakat hukum adat justru sebaliknya, pelakunya adalah orang yang terbunuh dan subjek korban adalah pihak yang dizinai berikut keluarganya. ${ }^{14}$ Harapan penegak hukum dapat

13 Hamid Abdullah, Manusia Bugis Makassar: Suatu Tinjauan Historis Terbadap Pola Tingkah Laku dan Pandangan Hidup Manusia Bugis Makassar, Inti Idayu Press, Jakarta, 1985, hlm. 5-6

14 Pada konteks kasus yang terjadi di kabupaten Jeneponto, masyarakat hukum adat memandang bahwa yang dimaksud sebagai pelaku adalah RM (yang menghamili), sedangkan korbannya adalah FT, pihak perempuan yang dihamilinya. Sementara pihak Pengadilan Negeri Jeneponto menempatkan sebaliknya, yakni RM sebagai korban dan keluarga FT sebagai pelaku, yakni; HR, SP, HS, dan WW. Demikian halnya dengan kasus di kabupaten Gowa, masyarakat hukum adat memandang bahwa yang dimaksud sebagai korban adalah HP dan keluarga dan pelakunya adalah AH dan HE, sedangkan bagi Pengadilan Negeri Gowa korban adalah AH, dan pelaku adalah beberapa orang dari pihak keluarga HP beserta kepala desa setempat, LG. Di sini perlu dipahami bahwa bahwa dalam konteks masyarakat hukum adat setempat, korban tidak hanya berimplilasi personal tapi 
memberi keadilan pada kedua belah pihak justru hanya semakin memperkeruh persoalan.

Kenyataan yang tampak dikotomis ini tentu saja tidak cukup dianalisis dalam kerangka pluralisme hukum seperti yang diterangkan oleh Maria Sumardjono, bahwa hukum adat hanya sebagai pelengkap dari hukum nasional. Pada konteks ini, digunakan pendekatan triangular interactive model of jurespundence dari Werner Menski untuk mengurai ketegangan keduanya. Teori ini mengkombinasikan teori hukum alam modern, positivisme, dan sosiologi hukum di tengah eurosentrisme dan sentralisme hukum. Bagi Menski, setiap jenis hukum mengandung elemen-elemen hukum negara sebagaimana yang ditegaskan oleh positivisme hukum; agama, etika, dan moralitas, sebagaimana yang disebutkan oleh teori hukum alam, dan masyarakat, seperti yang dianalisis oleh pendekatan sosiologi hukum. ${ }^{15}$ Ketiga jenis hukum ini dapat berinteraksi dan dikombinasinasikan dalam membentuk hukum negara, kendati setiap hukum ini memiliki arena yang berbeda-beda.

Pendekatan sosiologi hukum digunakan pada penelitian ini dalam rangka melihat secara empiris aktivitas sosial tempat hukum tampak sebagai suatu elemen dalam keyataan sosial. Bagi Menski, hukum normatif, positivisme hukum, dan hukum alam, tidak cukup valid untuk melihat aktivitas sosial. Pendekatan ini diharapkan dapat melengkapi dua jenis analisis lainnya sehingga memberikan gambaran yang terang dan komprehensif terhadap objek penelitian ini.

Topik ini pun bukan merupakan hal baru dalam diskursus hukum. Bahkan, dipenghujung abad ke-19 dan permulaan abab ke-20, F.J. Stimson ${ }^{16}$ dan Justice Kennedy ${ }^{17}$ telah menulis topik ini dengan baik setelah mencermati Amerika Serikat dan United Kingdom. Dalam konteks Indonesia, beberapa studi yang juga

\footnotetext{
juga kolektif (keluarga). Apa yang dialami korban dalam konteks masyarakat (FT dan HP) adalah juga dialami keluarganya. Selain itu, tindakan asusila yang terjadi di tempat tersebut dipercayai dapat menimbulkan petaka bagi seluruh warganya. Berbeda dengan itu, hakim dalam putusannya (Jeneponto; Nomor 22/Pid.B/2014/PN.JO, dan Gowa pada 2016; Nomor: 66/Pid.B/2012/PN. SUNGG, Nomor: 67/Pid.B/2012/PN. SUNGG, Nomor: 69/Pid.B/2012/PN. SUNGG, Nomor: 70/Pid.B/2012/PN. SUNGG.), justru melihat perkara ini secara personal dan individualistik

${ }^{15}$ Werner Menski, Comparative Law in a Global Context: The Legal System of Asia and Africa, Edisi Kedua, Cambridge University Press, Cambridge, 2006, hlm. 186-187

${ }^{16}$ F.J. Stimson, "National Univication of Law", Hardvard Law Review, Vol.7, No. 2, hlm. 92-106

${ }^{17}$ Justice Kennedy, "The Univication of Law", Journal of the Society of Comparative Legislation, Vol. 10, No. 2 ,
} hlm. 212-2019 
relevan dengan topik penelitian dilakukan di antaranya oleh Nyoman Serikat Putra Jaya $^{18}$ (2006), Reimon Supusesa ${ }^{19}$ (2012), Achmad Surya dan Suhartini ${ }^{20}$ (2019). Semua studi tersebut meskipun membahasa tentang hukum adat, namun tidak satu pun yang membahas unifikasi yang terjadi di Indonesia. Tiga topik terakhir yang lokusnya dilakukan di Indonesia belum tampak menunjukkan unifikasi tersebut.

Berdasarkan kerangka di atas, penelitian ini menjadi penting, bukan sematamata untuk kembali mengukuhkan hukum adat, tetapi untuk melihat persoalan hukum nasional dari sudut pandang yang lain, pluralisme hukum. Tujuannya agar khasanah keilmuan hukum dapat berlangsung secara dinamis dan dialektis pada satu sisi, serta memberikan sumbangan pemikiran terhadap perbaikan dan pengembangan hukum nasional ke depan.

\section{Rumusan Masalah}

Berdasarkan uraian latar belakang, rumusan masalah yang ingin dijawab dalam penelitian ini adalah, pertama, bagaimana sikap penegak hukum dalam menangani kasus tindak pidana pembunuhan berlatar belakang hukum adat di Sulawesi Selatan? Kedua, bagaimana bentuk unifikasi hukum yang terjadi di Sulawesi Selatan berikut implikasinya?

\section{Tujuan Penelitian}

Tujuan dari penelitian ini, pertama, mengetahui dan mengkaji sikap penengak hukum dalam memutuskan perkara pidana pembunuhan dalam hubungannya dengan hukum adat di Sulawesi Selatan. Kedua, menemukan bentuk unifikasi hukum berikut implikasinya.

\section{Metode Penelitian}

Jenis penelitian ini adalah penelitian hukum normatif. Penelitian ini difokuskan pada hasil putusan Pengadilan Negeri di dua kabupaten di Provinsi

18 Nyoman Serikat Putra Jaya, "Relevansi Hukum Pidana Adat dalam Pembaharuan Hukum Pidana Nasional”, Disertasi, Fakultas Hukum Universitas Diponegoro Semarang, 2006

${ }^{19}$ Reimon Supusesa, "Eksistensi Hukum Delik Adat dalam Perspektif Pembaruan Hukum Pidana Di Maluku Tengah", Jurnal Mimbar Hukum, Fakultas Hukum Universitas Gadjah Mada, 2012, Volume 24, Nomor 1

${ }^{20}$ Achmad Surya dan Suhartini, "Efektifitas Penyelsaian Tindak Pidana Ringan Melalui Lembaga Adat", Jurnal Hukum Ius Quia Iustum, Vol. 26, No. 2, 2019, hlm. 91-112 
Sulawesi Selatan, yakni Kabupaten Jeneponto dan Kabuaten Gowa tentang kasus pembunuhan yang bermotifkan hukum adat. Data penelitian ini terdiri atas tiga jenis: data hukum primer, sekunder, dan tersier. Data hukum primer mengacu pada putusan pengadilan negeri Jeneponto Nomor 22/Pid.B/2014/PN.JO, dan Gowa pada 2016; Nomor: 66/Pid.B/2012/PN. SUNGG, Nomor: 67/Pid.B/2012/PN. SUNGG, Nomor: 69/Pid.B/2012/PN. SUNGG, Nomor: 70/Pid.B/2012/PN. SUNGG., serta Kitab Undang-Undang Hukum Pidana (KUHP) dan pertauran perundang-undangan lainnya. Data sekunder adalah hasil wawancara yang dilakukan kepada beberapa narasumber, baik pelaku, korban, tokoh masyarakat hukum adat maupun penegak hukum: jaksa dan hakim. Data tersier adalah teks-teks yang relevan dengan topik penelitian, baik berupa putusan pengadilan, jurnal ilmiah maupun buku-buku.Teknik pengumpulan data dilakukan dengan dilakukan dengan cara dokumentasi dan wawancara. Dokumentasi dilakukan dengan menelusuri Putusan Pengadilan di dua lokasi penelitian ini, serta penelusuran data-data lain yang tersedia. Wawancara dilakukan kepada narasumber dengan bertemu langsung dan melalui via telepon.

Berdasarkan dari data yang tersedia ini, selanjutnya dianalisis dengan menggunakan pendekatan hukum komparatif (comparative legal approach) Werner Menski; positivisme hukum (legal positivism), hukum alam (natural law), dan sosiologi hukum (sosio-legal).Legal positivism dan natural law digunakan untuk melihat konteks justifikasi hukumnya dari penegak hukum (hakim dan jaksa), sedangkan sosio-legal atau sosiologi hukumnya untuk melihat konteks sosiologis di lokasi peristiwa ini berlangsung.

\section{Hasil Penelitian dan Pembahasan}

Sikap Penegak Hukum atas Tindak Pidana Pembunuhan Berlatar Belakang Hukum Adat?

\section{Tentang Masyarakat di Sulawesi Selatan}

Sulawesi Selatan adalah salah satu dari enam provinsi di kepulauan Sulawesi. Provinsi ini terletak di $0^{\circ} 12^{\prime}-8^{\circ}$ Lintang Selatan dan 116 $48^{\prime}-122^{\circ} 36^{\prime}$ Bujur Timur dengan luas wilayah 62.482,54 km². Batas wilayah Propinsi Sulawesi Selatan adalah sebelah utara berbatasan dengan Propinsi Sulawesi Tengah, 
sebelah barat berbatasan dengan Selat Makassar, sebelah timur berbatasan dengan Teluk Bone, dan sebelah selatan berbatasan dengan Laut Flores. Berdasarkan data Badan Pusat Statistik 2011, wilayah ini dihuni oleh sekitar 8.034.776 jiwa. ${ }^{21}$

Sulawesi Selatan secara administratif memiliki dua puluh empat wilayah kabupaten/kota. Dua di antaranya adalah lokasi penelitian ini dilakukan, yakni: Jeneponto dan Gowa. Demografi etnik penduduk di wilayah ini heterogen, namun kedua kabupaten yang disebutkan diidentifikasi sebagai etnik Makassar. Ini dapat diketahui dari bahasa dan tutur mereka yang berbahasa Makassar. Di tanah inilah Kerajaan Makassar (Gowa-Tallo') pernah berjaya padamasa lalu.

Eksistensi kerajaan iniperlahan pudar bersamaan dengan takluknya pada kolonial Belanda pada 1667, dan selanjutnya terintegrasi dengan Indonesia pada 1945. Namun, jejak kejayaan itu masih tampak, seperti adanya artefak-artefak kerajaan, hukum adat, sistem nilai, dan budaya. Artefak ini bisa disaksikan pada rumah kerajaan (Balla Lompoa) serta aksesoris kerajaan lain. Selain itu, lembaga adat Gowa yang masih eksis keberadannya hingga saat ini. Demikian pula dengan sistem nilai dan budaya yang masih tetap menjadi way of life di tengah masyarakat.

Lembaga hukum pun masih eksis dalam kehidupan sosial masyarakat. Faktanya, tidak sedikit masyarakat yang masih menyerahkah penyelesaian sengketa sosial melalui jalur hukum adat. Hal ini dapat diketahuidari fenomena masyarakat yang cenderung menyerahkan kasusnya kepada pemerintah setempat seperti Kepala Dusun, Iman Dusun, dan Kepala Desa, yang dipandang sebagai representasi hukum adat daripada melaporkannya kepada pihak berwajib, Kepolisian. Dalam terminologi hukum, jenis penyelesain ini disebut juga dengan jalur non-litigasi. Sebaliknya, penyelesaian sengketa melalui jalur peradilan (Pengadilan Umum (Negeri), Pengadilan Agama, Mahkamah Agung, Mahkamah Syariah, Peradilan Militer, serta Peradilan Tata Usaha Negara) disebut juga sebagai jalur litigasi. ${ }^{22}$

\footnotetext{
21 "Sulawesi Selatan Tahun 2011 Dalam Angka", https://sulsel.bps.go.id, diakses pada 2 Februari 2017

22 Ahmad Surya dan Suhartini, "Efektifitas Penyelsaian..., Op.Cit., hlm. 91-112
} 
Penyelesaian melalui jalan non-letigasi adalah hal yang lazim di kawasan ini, terlebih di kawasan masyarakat hukum adat. Polemik-polemik yang berlangsung diselesaikan melalui hukum adat atau lembaga pemerintah di tempat itu. Adapun penyelesaian melalui jalan litigasi cenderung hanya dilakukan di sekitar wilayah perkotaan dan oleh masyarakat kelas-kelas menengah atas. Realitas ini merupakan kenyataan sosial yang dapat disaksikan sehari-hari dalam masyarakat di dua lokasi penelitian inisecara khusus, dan Sulawesi Selatan secara umum.

\section{Penyelesaian Kasus Pidana Pembunuhan Menurut Kitab Undang-Undang Hukum Pidana (KUHP)}

Peristiwa pembunuhan berlatar belakang hukum adat yang berlangsung di dua kabupaten, yakni Jeneponto dan Gowa, pada akhirnya berujung pidana. Kedua kasus berbeda tempat, namun memiliki modus dan penyelesaian yang sama. Pembunuhan ini dilakukan oleh warga atas alasan hukum adat. Sebagai akibat dari tindakan tersebut, pelaku berhadapan dengan hukum positif (KUHP) melalui penyelesaian jalur litigasi. Segala argumentasi terkait hukum adat tidak berarti apa-apa dan tidak berdaya di hadapan pengadilan, bahkan tidak sebagai alasan yang meringankan sekalipun. Kedua kasus tersebut dipaparkan sebagai berikut.

Pertama, perkara pidana Nomor 22/Pid.B/2014/PN.JO. di Pengadilan Negeri Jeneponto tentang pembunuhan yang dilakukan secara bersama-sama dan terencana. Perkara ini terungkap setelah korban (RM) mengaku telah menyetubuhi keponakannya (FT) sendiri yang menyebabkannya kehamilan. Keadaan ini dalam istilah setempat disebut sapa'ritana (sumbangpati). Ini berawal dari pengakuan FT kepada orang tuanya bahwa ia telah dipaksa oleh pamannya sendiri untuk melayani nafsu bejatnya sebanyak tiga kali. FT tidak berani menyampaikan hal ini karena diancam akan dibunuh oleh RM. FT akhirnya menceritakan peristiwa yang dialaminya kepada orang tuanya. Orang tua FT tidak menerima peristiwa yang dialami anaknya, lantas melaporkan kejadian ini pada Forum Masyarakat di desanya. RM kemudian dihadapkan pada peradilan adat setempat melalui forum tersebut, dan selanjutnya dijatuhi sanksi berdasarkan hukum adat. Sanksi tersebut berupa diusir dan dibuang dari 
kampung, dan apabila dikemudian hari sanksi ini tidak diindahkan oleh RM, maka pihak keluarga ${ }^{23}$ korban diperkenankan bertindak sesuai kehendaknya, termasuk membunuhnya. Seminggu kemudian, RM tidak meninggalkan desanya. Ia diketahui oleh keluarga FT sedang berada di kampung tersebut mengunjungi rumah kerabatnya. Hal tersebut memicu reaksi keluarga korban. Akibatnya, RM pun dibunuh secara bersama-sama oleh keluarga korban yang inisialnya adalah HR, SP, HS, dan WW. Atas kasus ini, Majelis Hakim menetapkan tiga orang, kecuali HR, sebagai terdakwa dengan pidana penjara masing-masing selama tiga belas tahun.

Kedua, perkara pidana Nomor 66/Pid.B/2012/PN.SUNGG, Nomor 67/Pid.B/2012/PN.SUNGG, Nomor 69/Pid.B/2012/PN.SUNGG, dan Nomor 70/Pid.B/2012/PN.SUNGG., di Pengadilan Negeri Gowa. Peristiwa ini hampir serupa dengan putusan yang terjadi di Jeneponto. Kasus ini melibatkan banyak orang, termasuk struktur desa setempat; kepala Desa Majannang (LG). Pada konteks ini, sebagaimana yang telah dijelaskan sebelumnya bahwa Desa dan Kepala Desa dalam alam pikiran masyarakat hukum adat adalah sekaligus menjadi pemangku adat.

Keterlibatan LG berawal dari laporan HP yang mendapati istrinya, HE, sedang berzina dengan karyawannya, AH, di rumahnya. Kejadian ini kemudian dilaporkan oleh HP ke Kepala Desa dan selanjutnya dilakukan rapat adat. Hasilnya, pelaku, HE dan AH,dibuang dari desa selama tujuh turunan. Dengan kata lain, keduanya tidak diperkenankan lagi menginjakkan kakinya di kawasan ini. Sanksi tersebut tidak diindahkan oleh AH,la ntaran beberapa hari kemudian, AH masih berada di sekitar desa Majannang.

Informasi tersebut memicu reaksi warga dan Kepala Desa. Akibatnya, terjadi pembunuhan secara bersama-sama terhadap AH. Peristiwa ini meskipun dilakukan oleh banyak orang, namun majelis Hakim Pengadilan Negeri Jeneponto hanya menetapkan beberapa orang menjadi tersangka, yakni HM dengan pidana penjara selama dua belas tahun, $\mathrm{BD}$ dengan pidana penjara

${ }^{23}$ Perlu diketahui di sini, kata "keluarga" bukan hanya secara genetik, tapi juga jamak (massa), karena termasuk pada warga kampung tersebut. Mengapa demikian, karena masyarakat mempercayai bahwa suatu tindakan asusila yang dilakukan di daerah mereka, dapat menyebabkan bala dan petaka bagi seluruh warga tersebut 
selama delapan tahun, LG dengan pidana penjara selama sepuluh tahun, dan ME dengan pidana penjara selama delapan tahun.

Aparat penegak hukum, khususnya hakim, dalam memutus perkara ini menitikberatkan pada penegakan asas legalitas hukum pidana (Pasal 1 ayat (1) KUHP), dan menegasikan norma budaya. Hakim dalam memeriksa serta menjatuhkan putusan umumnya hanya mengacu pada pasal pidana yang telah diatur dalam KUHP, tanpa adanya pertimbangan lain. Terbukti dalam amar putusan pengadilan, majelis hakim sama sekali tidak mencantumkanalasan pelaku/terdakwa yang tindakannya didasari atas penegakan hukum adat dan konsensus sosial. Majelis hakim dalam pertimbangannya cenderung mengabaikan bukti-bukti yang terungkap dalam proses pemeriksaan persidangan, misalnya alasan terdakwa dalam melakukan suatu tindak pidana. ${ }^{24}$

\section{Analisis Kecenderungan Unifikasi di Tengah Pluralitas Hukum.}

Dua peristiwa yang telah dipaparkan menunjukkan hukum nasional sedemikian dominan dan hegemonik di tengah hukum adat. Kenyataan ini disebut oleh Tania Murray Li sebagai kompleksitas yang kontradiktif (contradictory complexity). Dalam artikelnya yang berjudul, Masyarakat Adat, difference, and limits of recognition in Indonesia's Forest Zone, Li menjelaskan bahwa masyarakat adat selama ini tidak lebih sebagai subaltern, yakni masyarakat yang tidak berdaya. Hak-hak mereka dikebiri oleh kolompok mayoritas dan bahkan

\footnotetext{
${ }^{24}$ Putusan hakim di Kabupaten Jeneponto berdasarkan pada putusan No. 22/Pid.B/2014/PN.JO., memberikan pertimbangan yang memberatkan, bahwa: 1) Perbuatan para terdakwa mengakibatkan matinya/hilangnya nyawa korban RM; 2) Perbuatan Para Terdakwa di lakukan secara sadis; 3) Perbuatan para Terdakwa mengakibatkan penderitaan yang mendalam bagi keluarganya. Sedangkan pertimbangan yang meringankan adalah; 1) Para terdakwa bersikap sopan dalam persidangan dan menyesali perbuatan; 2) Para terdakwa memiliki tanggungan keluarga; 3) Para terdakwa belum pernah dihukum. Sehingga pada masing-masing terdakwa (SY, HY, WR) dipidana penjara 13 (tigah belas) tahun. Hal yang sama juga terjadi di kabupaten Gowa. Ini dapat diketahui pada putusan majelis hakim No. 69/Pid.B/2012/PN. SUNGG., yang dalam yang memberatkan, memutuskan bahwa; Perbuatan terdakwa meresahkan masyarakat dan Perbuatan terdakwa di lakukan secara sadis. Adapun pertimbangan yang meringankan adalah karena terdakwa belum pernah dihukum dan Terdakwa berusia lanjut. Mengingat Pasal 340 KUHP jo. Pasal 55 ayat (1) ke- 2 KUHP serta Pasal 193 ayat (1) KUHAP disertai berbagai pertimbangan maka majelis hakim menjatuhkan putusan sebagai berikut: 1) bersalah melakukan tindak pidana "turut serta melakukan pembunuhan berencana"; 2) Menjatuhkan pidana kepada terdakwa Labbiri Dg. Gama bin Dekke dengan pidana penjara selama 10 (sepuluh) tahun; 3) Menetapkan agar masa penahanan sementara yang telah di jalani oleh terdakwa dikurangkan selurunya dari pidana yang di jatuhkan; 4) Memerintahkan agar terdakwa tetap berada dalam tahanan. Putusan hakim ini tidak ubahnya dengan tiga putusan lainnya di tempat ini Dari empat di Kabupaten Jeneponto (No. 66/Pid.B/2012/PN. SUNGG, No. 67/Pid.B/2012/PN. SUNGG, No. 69/Pid.B/2012/PN. SUNGG, dan No. 70/Pid.B/2012/PN. SUNGG.). pada pertimbangan meringankan bagian kedua di Jeneponto, bahwa terdakwa menyesali perbuatan, justru tampak berbeda dengan keterangan keluarga saat diwawancarai oleh peneliti
} 
oleh negera itu sendiri. ${ }^{25} \mathrm{Hal}$ ini dapat diketahuidari putusan hakim sebagai "tangan" negera menyelesaikan perkara ini.

Perjuangan hak-hak masyarakat adat ini telah berlangsung bersamaan dengan dengan berakhirnya rezim Orde Baru, namun hingga saat ini masih mengalami pasang surut. Ini dapat diketahuidari perjuangan yang dilakukan oleh Aliansi Masyarakat Adat Nasional (AMAN) dengan mengorganisir kelompokkelompok masyarakat hukum adat. Pengakuan atas hak-hak mereka masih problematis, meskipun pada sisi lain tetap diakui sebagai warga negara. Dengan kata lain, mereka sebagai kelompok masyarakat yang memiliki sistem hukum dan ideologi belum terakomodir. Pada konteks inilah hukum adat belum mendapat tempat dalam sistem hukum di Indonesia, meskipun memiliki peran yang sama dengan hukum lainnya termasuk hukum nasional. Sebagai buktinya adalah peristiwa yang telah dipaparkan, bahwa hukum negera bertindak sewenangwenang atasnya. Sementara bagi mereka, seperti diterangkan oleh A. Hardiman²6 bahwahukum adat tidak ubahnya hukum nasional yang juga memiliki dua kepentingan, yakni: 1) untuk kepentingan sosial kemasyarakatan sebagai wujud kesadaran bahwa mereka sebagai bagian dari masyarakat, dan; 2) untuk kepentingan individu yang saling menghargai dan memanusiakan.

Kedua kasus ini dalam amar putusan hakim dikaji an sich sebagai tindak pidana pembunuhan. Deraan yang diberikan kepada pelaku hanya di sekitar Pasal 340 KUHP, 27 dan Pasal 55 ayat (1) ke 1 KUHP28 dengan unsur-unsur: 1) barangsiapa; 2) dengan sengaja; 3) direncanakan lebih dahulu; 4) menghilangkan nyawa orang lain; 5) mereka yang melakukan, yang menyuruh melakukan dan yang turut serta melakukan. Kepala Desa yang terlibat pada kasus di Kaputen Gowa justru mendapat tambahan sanksi Pasal 56 ke-2 KUHP. ${ }^{29}$

\footnotetext{
25 Tania Murray Li, "Masyarakat Adat, difference, and limits of recognition in Indonesia’s Forest Zone", Journal of Modern Asian Studies, Vol. 35, No. 3, 2001, hlm. 650-651

${ }^{26} \mathrm{~A}$. Hardiman, tokoh adat Jeneponto, Wawancara, Kecamatan Arungkeke, Kabupaten Jeneponto, pada Sabtu, 12 Mei 2018

${ }_{27}$ Barangsiapa dengan sengaja dan dengan rencana terlebih dahulu merampas nyawa orang lain, diancam karena pembunuhan dengan rencana, dengan pidana mati atau pidana penjara seumur hidup atau selama waktu tertentu, paling lama dua puluh tahun

${ }^{28}$ Mereka yang melakukan, yang menyuruh melakukan, dan yang turut serta melakukan perbuatan

${ }^{29}$ Dipidana sebagai pembantu kejahatan: (1) mereka yang sengaja memberi bantuan pada waktu kejahatan dilakukan; (2) mereka yang sengaja memberi kesempatan, sarana atau keterangan untuk melakukan kejahatan
} 
Pelanggaran yangdilakukan oleh masing-masing terdakwa pada dasarnya merupakan bagian dari sanksi hukum adat. Hal ini dilakukan sebagai bentuk sanksi lain dan konsekuensi dari pelaku yang tidak mengindahkanhukum adat. Seperti diterangkan oleh Amiruddin Daeng Jarre, ${ }^{30}$ tokoh masyarakat di Jeneponto, bahwa:

"Anjo punna dimassai taua angkanayya punna nia tau sapa'ritana'. Ni massai nasaba' anyyalai nammpa tena napaentengi siri'na. Napunna digappai ri tau toana na tau assari'na bainea nakulle ni massai buranea"

Diterjemahkan secara bebas:

"Sanksi adat A'massa dapat dilaksanakan bila seseorang melakukan perbuatan sumbang pati (hubungan sedarah) dikarenakan hal tersebut menyalahi aturan adat serta dianggap tidak menegakkan siri' nya. Apabila ditemukan oleh pihak orang tua maupun orang lain disekitarnya, maka dimungkinkan untuk diberikan sanksi $A^{\prime} m a s s a$.

Tindakan terdakwa dalam konteks hukum adat tidak dapat dikatakan sebagai penganiayaan an sich seperti definisi hakim, tetapi sebagai suatu proseder hukum dalam masyarakat hukum adat. Sebagaimana diakui oleh Daeng Jarre bahwa fenomena ini bukan terjadi kali ini saja melainkan telah ada sejak dulu. Fakta ini diperkuat oleh hasil penelitian dari Muhammad Ruslan Affandy yang berjudul "Analisis Hukum Terhadap Eksistensi Adat A'massa pada Delik Silariang di Kabupaten Jeneponto."Affandi ${ }^{31}$ dalam paparannya menjelaskan bahwa sanksi hukum adat A'massa masih merupakan bagian dari eksistensi hukum dalam masyarakat Jeneponto. Ini semakin jelas dari kenyataan bahwa tidak seorang pun dari pihak keluarga korban (baik RM maupun AH) yang merasa keberatan. Hal ini mengindikasikan bahwa keluarga korban menerima sepenuhnya sanksi yang dijatuhkan oleh peradilan adat sebagai konsekuensi dari kealpaan dan keangkuhan korban yang tidak mengindahkan sanksi tersebut. Perkara ini menjadi semakin runyam dan berujung pidana berdasarkan inisiatif dari pihak kepolisian dan pengadilan, bukan berdasarkan laporan keluarga dari pihak korban. Sebaliknya, keluarga terdakwa di pihak lain merasa bahwa putusan

\footnotetext{
${ }^{30}$ Amiruddin Daeng Jarre, tokoh adat Jeneponto, Wawancara, Desa Bontosunggu Kecamatan Tamalate Kabupaten Jeneponto, pada Minggu, 13 Mei 2018

${ }^{31}$ Muhammad Ruslan Affandy, "Analisis Hukum Terhadap Eksistensi Adat A'massa pada Delik Silariang di Kabupaten Jeneponto”, Skripsi, Fakultas Hukum Universitas Hasanuddin Makassar, 2016, hlm. 161
} 
hakim yang dijatuhkan kepada para terdakwa tidak memenuhi nilai keadilan.

Muliati selaku keluarga dari pihak terdakwa di Jeneponto mengungkapkan bahwa:

Ngapa nakulle bijangku ammunoi nasaba ka anu nibongkamo injo mae ri kamponga tapi tama kinjai, alasannacocoki iyya panggaukanga ribunoi appatekaananga nasaba naakui anjo baine na nampa passala' Siri' na bijang inne erokna paentengka kamanakanna tonji napakateanang, Karaeng. Tena na cocok keputusanna nasaba sallo dudui hukumannna battu ri hakim nga, Karaeng, nasaba na sesuaimi perbuatanna nampa tenamo paboya kanreku Karaeng, na nakke mi inne kamma-kamma paboya kanrena ballaku, nakke mami tulang punggung keluarga. ${ }^{32}$

Diterjemahkan secara bebas:

Kenapa bisa keluargaku melakukan pembunuhan karena orang itu telah memasuki kampung ini padahal telah diusir (telah ada keputusan hukum adat mengusir korban dari kampung). Apa yang dilakukan oleh keluargaku sudah sesuai karena Siri' yang harus ditegakkan, sebab yang bersangkutan telah menghamili keponakannya sendiri. Tidak cocok putusannya hakim karena hukuman yang diberikan terlalu lama, hal ini mengakibatkan tidak ada pencari makan, tidak ada lagi yang mencari nafkah (berkebun), Tuanku, tersisa saya yang menjadi tulang punggung keluarga.

Kenyataan ini menunjukkan bahwa penerapan hukum adat seringkali dipandang sebagai suatu kejahatan oleh hukum negara. Sebagaimana juga diungkapkan oleh Muhammad Arief bin Sempo, salah satu terdakwa kasus di Gowa (kasus splitsing dari kasus yang diuraikan penulis) bahwa:

"Pada saat saya diperiksa dalam pemeriksaan sidang di Pengadilan Negeri Sungguminasa, berulang kali saya katakan bahwa perbuatan yang saya lakukan adalah perbuatan yang dibenarkan menurut konsep hukum adat. Majelis hakim tidak mempertimbangkan perihal ini, termasuk nilai (budaya) Siri' na Pacce". 33

Oleh sebab itu, Arief merespon keputusan hakim pengadilan Negeri Sungguminasa (Gowa) dengan upaya hukum banding pada Pengadilan Tinggi Sulawesi Selatan. Adapun hasilnya tetap nihil, karena delapan tahun penjara yang menjadi hukumannya tidak berubah pada putusan pengadilan tinggi. Mei 2018

${ }^{32}$ Muliati, istri tersangka HR, Wawancara, Desa Bonto Rappo Kabupaten Jeneponto, pada Minggu, 13

${ }^{33}$ Muhammad Arief bin Sempo, tersangka, Wawancara, Kecamatan Sungguhminasa Kabupaten Gowa,pada Kamis, 14 Juni 2018 
Adapun Muliati, keluarga terdakwa kasus di Jeneponto, dalam menanggapi putusan hakim tersebut, berpendapat bahwa:

"Nakke inne tena kuissengi pakinjoan ka katte inne tau biasa jiki, tena kiissengi nikanayya "hukum negara". Panganreang injo sukkara niboya, jari tea maki kana a'boya rungan maraeng, tena niisenggi nikanaya "upaya hukum". Passangmi pale keputusanna pengadilanga kammanjo manna na pa' risiji nyawayya tarimai"

Diterjemahkan secara bebas:

Saya ini tidak tahu soal begituan karena kami ini rakyat biasa tidak tahu soal "hukum negara." Untuk makan saja kami susah, jadi tidak usah mengatakan untuk menempuh "upaya hukum." Biarlah kami terima putusannya pengadilan seperti itu meskipun kami sakit hati menerimanya.

Di pihak lain, Jaksa Penuntut Umum, Budi Utama, memberikan keterangan terkait kasus pembunuhan di Jeneponto, bahwa:

"Dapat saya jelaskan bahwa dalam membentuk atau menyusun surat dakwaan dari kami (jaksa penuntut umum) tetap berdasar pada hukum positif yang berlaku. Tindak pidananya sendiri waktu itu adalah pembunuhan sehingga pasal-pasal yang dikenakan pada saat itu adalah Pasal 340 subsidair Pasal 338 KUHP. Khusus untuk tuntutan, tentunya untuk kami di internal kejaksaan terdapat pertimbangan-pertimbangan dalam mengajukan tuntutan sebelum tuntutan tersebut dibacakan. Salah satu pertimbangan yang diambil waktu itu adalah budaya yang berlaku di masyarakat. Ketika tindak pidana tersebut tentunya berhubungan dengan budaya yang dianut oleh masyarakat maka tentunya kami (jaksa penuntut umum) menjadikan hal tersebut sebagai pertimbangan untuk meringankan tuntutan. Dalam melakukan penuntutan jaksa juga berpegang pada pedoman penuntutan. Dalam pedoman penuntutan tersebut telah diatur juga hal-hal yang mempengaruhi faktor pertimbangan jaksa dalam meringankan atau memberatkan tuntutan. Terkait soal kasus di Jeneponto, kami selaku jaksa menjadikan alasan penegakan Siri' oleh terdakwa sebagai alasan untuk meringankan tuntutan para terdakwa. ${ }^{34}$

Penjelasan Jaksa Penuntut Umum meskipun menyebutkan bahwa dirinya mempertimbangkan unsur budaya, namun dalam persidangan tidaklah demikian. KUHP adalah instrumen tunggal dalam memutus perkara tersebut.

\footnotetext{
${ }^{34}$ Budi Utama, SH.,MH., Jaksa Penuntut Umum, Wawancara, pada hari Minggu, tanggal 13 Mei 2018. Wawancara ini dilakukan melalui via telepon karena saat penelitian ini dilakukan yang bersangkutan sudah tidak bertugas Kejaksaan Negeri Jeneponto tetapi sudah dipindahtugaskan ke Kejaksaan Negeri Luwu Sulawesi Selatan
} 
Hilman Hadikusuma ${ }^{35}$ menjelaskan bahwa penyelesaian perkara melalui peradilan adat oleh lembaga adat bukan bertujuan semata-mata mendapatkan putusan yang tetap, melainkan penyelesaian yang menjamin keseimbangan dalam masyarakat, sehingga daripadanya para pihak yang berkepentingan dapat menjadi rukun (kembali) tanpa adanya rasa dendam. Hal seturut juga dikemukakan oleh Bushar Muhammad bahwa penyebab masyarakat lebih memilih menyelesaikan delik adat melalui peradilan adat karena dipandang lebih dapat memberikan keseimbangan dan ketentraman. ${ }^{36}$

Pada konteks ini, hukum negara yang sejatinya mewujudkan rasa keadilan pada warga, justru mengebiri esensi hukum itu sendiri. Hukum negara dalam hal ini berdiri dominan dan mengambil posisi dominan. Hukum yang sejatinya menjadi wahana untuk mewujudkan keadilan justru menutup distribusi keadilan. Dengan kata lain, hukum negara menutup mata atas keberadaan hukum lain yang hidup di tengah masyarat. Sementara di Indonesia, sebagaimana diakui oleh Bryan S. Turner dalam artikelnya Legal Pluralism, State Sovereignity, and Citizenship, ${ }^{37}$ pluralistas hukum dan ketegangan di antara hukum adat (costumary law), hukum agama, dan hukum Eropa (KUHP/positif) merupakan suatu kenyataan yang kompleks. Menurut Turner, tanpa adanya frame pluralisme hukum (legal pluralism) pada kenyataan yang demikian, ini menjadi suatu keadaan yang berbahaya (a real danger) karena antara satu hukum dengan hukum-hukum yang lain saling terpisah-pisah. Lebih jauh dijelaskan bahwa, multiculturalism without some powerful framework of shared interests and shared institutions cannot provide an adequate cultural framework for any complex society. ${ }^{38}$ Kenyataan inilah yang tampaknya gagal dipahami oleh aparat penegak hukum sehingga tidak mengakomodasi hukum adat dan nilai-nilai budaya dalam hukum pidana nasional.

\section{Penutup}

Berdasarkan pembahasan, dapat disimpulkan bahwa, pertama, sikap penegak hukum, dalam hal ini jaksa dan hakim, atas kasus tindak pidana

\footnotetext{
${ }^{35}$ Hilman Hadikusuma, Pengantar Ilmu Hukum Adat Indonesia, Mandar Maju, Bandung, 2003, hlm. 10

${ }^{36}$ Bushar Muhammad, Asas-Asas Hukum Adat: Suatu Pengantar, Pradnya Paramita, Jakarta, 1976, hlm. 55

${ }^{37}$ Bryan S. Turner, "Legal Pluralisme, State Sovereignity, and Citizenship,"Journal of Democracy and Security, Routledge, 2011, hlm. 318-337

${ }^{38}$ Ibid...
} 
pembunuhan berlatar belakang hukum adatdi Sulawesi Selatan adalah sepenuhnya menunggunakan hukum positif. Hal ini terlihat dari pertimbanganpertimbangan putusan hakim pengadilan,baik yang terjadi di kabupaten Jeneponto maupun di kabupaten Gowa, yang mengabaikan pertimbangan hukum yang lain, yakni hukum adat. Kedua, konsekuensi dari praktik hukum yang formalistik dan normatif ini terhadap unifikasi hukum adalah bahwa pluralitas hukum,sebagai sebuah kenyataan sosial, direduksi atas nama hukum positif, KUHP. KUHP berdiri di atas hukum-hukum yang lain, sementara hukum lainnya yang justru lebih mapan menjadi tidak berdaya. Pada konteks ini, Indonesia yang menganut sistem hukum yang identik dengan rule of law belum mengarusutamakan hukum adat dan pada praktiknya justru menerapkan sistem negara hukum yang identik dengan rechsstaat, yang cenderung positivistik. Hukum materiil diabaikan dan keadilan hanya berada di atas kertas. Sebagai implikasinya, spitit of law pada masyarakat memudar dan ketidakpercayaan publik terhadap penegak hukum (negara) meningkat.

\section{Daftar Pustaka}

\section{Buku}

Abdullah, Hamid, Manusia Bugis Makassar: Suatu Tinjauan Historis Terhadap Pola Tingkah laku dan Pandangan Hidup Manusia Bugis Makassar, Inti Idayu Press, Jakarta, 1985.

Atmasasmita, Romli, Teori Hukum Integratif (Rekonstruksi Terhadap Teori Hukum Pembangunan dan Teori Hukum Progresif), Genta Publishing, Yogyakarta, 2012.

Hadikusuma, Hilman, Pengantar Ilmu Hukum Adat Indonesia, Mandar Maju, Bandung, 2003.

MD., Moh. Mahfud, Hukum dan Pilar-Pilar Demokrasi, Gama Media, Yogyakarta, 1999.

Menski, Werner, Comparative Law in a Global Context: The Legal System of Asia and Africa, (2and ed.), Cambridge University Press, Cambridge, 2006.

Raharjo, Satjipto, Negara Hukum yang Membahagiakan Rakyatnya, Genta Publishing, Yogyakarta, 2009.

Sudjito, Hukum Dalam Pelangi Kehidupan, Gadjah Mada University Press, Yogyakarta, 2012. 
Susanto, Anthon F., Ilmu Hukum Non Sistematik: Pondasi Filsafat Pengembangan Ilmu Hukum Indonesia, Genta Publishing, Yogyakarta, 2010.

\section{Hasil Penelitian}

Jaya, Nyoman Serikat Putra, Relevansi Hukum Pidana Adat dalam Pembaharuan Hukum Pidana Nasional, Disertasi, Fakultas Hukum Universitas Diponegoro, Semarang, 2006.

Affandy, Muh. Ruslan, Analisis Hukum Terhadat Eksistensi Sanksi Adat A'Massa pada Delik Silariang di Kabupaten Jeneponto (Studi Kasus di Desa Kapita, Kecamatan Bangkala, Kabupaten Jeneponto,Skripsi,Fakultas Hukum Universitas Hasanuddin, Makassar, 2016.

Gani, Andika Wahyudi, Eksistensi Nilai Budaya Siri' naPacce Terhadap Tindak Pidana Pembunuhan Berdasarkan Asas Legalitas Pada Masyarakat BugisMakassar, Disertasi, Fakultas Hukum Universitas Gadjah Mada, Yogyakarta, 2018.

\section{Jurnal}

Kennedy, Justice, "The Univication of Law",Journal of the Society of Comparative Legislation, Vol. 10, No. 2, 1902.

Li, Tania Murray, "Masyarakat Adat, difference, and limits of recognition in Indonesia's Forest Zone", Modern Asian Studies, Vol. 35, No. 3, 2001.

Likadja,Jeffry Alexander Ch., "Memaknai "Hukum Negara (Law Through State)" dalam Bingkai “NegaraHukum (Rechtstaat)",JurnalHasanuddin Law Review, Vol. 1, No. 1, 2015.

Suhadi, Imam, "Hukum dan kekuasaan", Jurnal Hukum, Vol. 3, No. 6, 1999.

Stimson, F.J., "National Univication of Law”, Hardvard Law Review, Vol. 7, No. 2, 1892.

Supusesa, Reimon, "Eksistensi Hukum Delik Adat Dalam Perspektif Pembaruan Hukum Pidana Di Maluku Tengah", Jurnal Mimbar Hukum, Vol. 24, No. 1, 2012.

Surya, Achmad dan Suhartini, "Efektifitas Penyelsaian Tindak Pidana Ringan Melalui Lembaga Adat", Jurnal Hukum Ius Quia Lustum-UII, Vol. 26, No. 2, 2019.

Turner, Bryan S., "Legal Pluralisme, State Sovereignity, and Citizenship", Juornal of Democracy and Security, Routledge, 2011.

\section{Makalah/Pidato}

Sumardjono, Maria S.W., Pluralisme Hukum dalam Pengaturan Sumber Daya Alam di Indonesia, Adaptasi, Harmonisasi dan Agenda ke Depan.Pidato yang disampaikan pada Rapat Senat Terbuka dalam rangka Dies Natalis ke-71, Fakultas Hukum Universitas Gadjah Mada, Yogyakarta, 13 Februari 2017 
Majalah

Manan, Bagir, "Mengadili Menurut Hukum”, Majalah Hukum Varia Peradilan, No. 238, Jakarta, 2005.

\section{Internet}

"Sulawesi Selatan Tahun 2011 Dalam Angka", https://sulsel.bps.go.id, diakses tanggal 2 Februari 2017.

\section{Peraturan Perundang-undangan}

Undang-Undang Dasar Negara Republik Indonesia Tahun 1945

Undang-Undang No. 19 Tahun 1948 tentang Susunan dan Kekuasaan Badanbadan Kehakiman dan Kejaksaan.

Undang-Undang Nomor 19 Tahun 1964, tentang Ketentuan-Ketentuan Pokok Kekuasaan Kehakiman.

Undang-Undang No. 14 Tahun 1970 tentang Ketentuan-Ketentuan Pokok Kekuasaan Kehakiman

Undang-Undang No. 4 Tahun 2004 tentang Kekuasaan Kehakiman

\section{Putusan Pengadilan}

Putusan Pengadilan Negeri Jeneponto Perkara Pidana Nomor: 22/Pid.B/2014/PN.JO/2012.

Putusan Pengadilan Negeri Gowa Perkara Pidana Nomor: 66/Pid.B/2012/PN. SUNGG, Nomor: 67/Pid.B/2012/PN. SUNGG, Nomor: 69/Pid.B/2012/PN. SUNGG, Nomor: 70/Pid.B/2012/PN. SUNGG. 